\title{
A review on the definitions of terms of sedimentary facies
}

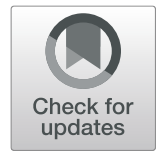

Zeng-Zhao Feng

\begin{abstract}
In recent years, in some papers and manuscripts published in and submitted to the Journal of Palaeogeography (Chinese Edition and English Edition), the authors named the rocks or rock types as "microfacies" or "lithofacies", named the microfeatures in thin-sections under microscope as "microfacies", and named the macrofeatures of rocks as "macrofacies". I wrote two short papers "Words of the Editor-in-Chief — Rocks are not microfacies" (Feng, Journal of Palaeogeography 19(5):II 2017) and "Words of the Editor-in-Chief — Rocks are not lithofacies" (Feng, Journal of Palaeogeography 20(3):452-452, 2018) which were in Chinese and published in the Journal of Palaeogeography (Chinese Edition). However, they did not attract much attention of readers in China and outside China. In addition, in 1980s, some Chinese sedimentologists proposed "subfacies" and "microfacies" based on the macrofeatures of rocks from outcrops and drilling cores. However, the definition of this "microfacies" is totally different from the "microfacies" proposed by foreign sedimentologists in 1940s based on the microfeatures in thin-sections under microscope.

These problems appeared repeatedly and forced me, as the Editor-in-Chief of the Journal of Palaeogeography (Chinese Edition and English Edition), to observe the policy of "A hundred flowers blossom and a hundred schools of thought contend" , to write new papers "A review on the definitions of terms of sedimentary facies" both in Chinese and in English, to clarify the definitions of the terms of sedimentary facies, i.e., "facies", "lithofacies", two "microfacies", "macrofacies", "subfacies", etc. I hope that the new papers will attract attention of readers worldwide and they can write papers and participate in the discussion and contending of these problems, strive for getting some common understandings, and therefore promote the progress and development of sedimentology and palaeogeography.
\end{abstract}

Keywords: Sedimentary facies, Facies, Lithofacies, Microfacies, Macrofacies, Subfacies, A hundred flowers blossom and a hundred schools of thought contend

\section{Introduction}

In 2014, in the paper by Hou et al. (2014) published in the Journal of Palaeogeography (Chinese Edition), the authors named the rocks as "microfacies". I suggested them to utilize rocks or rock types instead of "microfacies". They accepted my suggestion.

In 2015, in the papers published in the Journal of Palaeogeography (English Edition), the authors named the rocks as "lithofacies", named the microfeatures of rocks as "microfacies", and named the macrofeatures of rocks as "macrofacies". I suggested the authors to utilize

Correspondence: jpalaeo2012@163.com

Editorial Office of Journal of Palaeogeography, P. O. Box 902, China University of Petroleum (Beijing), No. 20 Xueyuan Road, Haidian District, Beijing 100083, China "rocks" or "rock types", "microfeatures of rocks" and "macrofeatures of rocks" instead of "lithofacies", "microfacies" and "macrofacies" respectively. However, they did not accept my suggestion. At that time, I thought it may be the difference of academic viewpoints between us, I could not force them to change their points of view.

In 2017, the Journal of Palaeogeography (Chinese Edition) received a manuscript by $\mathrm{Xi}$ et al. (2017). The authors considered 10 rock types as 10 "microfacies" and indicated that the 10 "microfacies" are identified based on the "standard microfacies" in the Chinese version of the book "Carbonate Facies in Geologic History" by Wilson (1975a, b) of which the chief translator was me.

I wrote a letter to Dr. Xi and expressed my viewpoint that the 10 "microfacies" in their manuscript are not
Springer Open

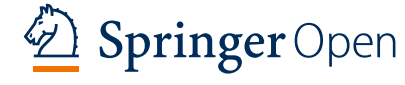

(c) The Author(s). 2019 Open Access This article is distributed under the terms of the Creative Commons Attribution 4.0 International License (http://creativecommons.org/licenses/by/4.0/), which permits unrestricted use, distribution, and reproduction in any medium, provided you give appropriate credit to the original author(s) and the source, provide a link to the Creative Commons license, and indicate if changes were made. 
"microfacies" but 10 rocks or rock types. I hope he will agree with my idea. Meanwhile, I wrote a short paper "Words of the Editor-in-Chief - Rocks are not microfacies" (Feng 2017, in Chinese) and planned for publishing both the papers of Xi et al. and minein the Journal of Palaeogeography (Chinese Edition) in the same issue in order to attract the attention of readers.

Dr. Xi accepted my suggestion. The papers of Xi et al. and mine were published in the Journal of Palaeogeography (Chinese Edition), Xi et al. 2017, Vol. 19, No.5. After a few days, I received some emails from readers, they agreed with my viewpoint.

In October 2017, the $6^{\text {th }}$ National Congress of Sedimentology was held at Nanjing. Some presenters considered rocks or rock types as "microfacies" or "lithofacies" in their presentations. During the discussions of these presentations, I said: "These rocks or rock types are not "microfacies" or "lithofacies", because these terms don't include sedimentary environment". Many attendees applauded my speech and agree with my ideas.

In October 2017, the Journal of Palaeogeography (Chinese Edition) received a manuscript by Liu et al. and the authors considered 16 rocks as "lithofacies". I suggested them to utilize rocks or rock types instead of "lithofacies". However, they did not accept my suggestion. Hence, I wrote a short paper "Words of the Editorin-Chief - Rocks are not lithofacies" (Feng 2018, in Chinese) and this paper was published together with the paper of Liu et al. in the Journal of Palaeogeography (Chinese Edition) in the same issue, Liu et al. 2018, Vol.20, No.3, and let readers discuss this problem.

In January 2018, the Journal of Palaeogeography (English Edition) received two manuscripts. The authors of one paper considered 23 rock types as 23 "microfacies" and indicated that their "microfacies" are based on the definition of microfacies proposed by Flügel (2004a, b; 2010a, b). The authors of the other paper considered 11 rocks as 11 "lithofacies".

The same problem appeared again and again.

In addition, in 1980s, some Chinese sedimentologists proposed "subfacies" and "microfacies" according to macrofeatures of outcrops and drilling cores. The definition of this "microfacies" is totally different from the "microfacies" proposed by foreign sedimentologists in 1940s based on the microfeatures in thin-sections under microscope. In sedimentary petrology and sedimentology, there are two "microfacies" with different definitions at the same time. It is a very tough problem.

These problems forced me, as the Editor-in-Chief of the Journal of Palaeogeography (Chinese Edition and English Edition), to observe the policy of "A hundred flowers blossom and a hundred schools of thought contend" , to write new papers both in Chinese and in English, to clarify the definitions of the terms of sedimentary facies, such as "facies", "sedimentary facies", "lithofacies", two "microfacies", "macrofacies", "subfacies", etc..

The new papers are "A review on the definitions of terms of sedimentary facies (both in English and Chinese)".

I hope that the new papers will attract attention of readers worldwide and they can write papers and participate in the discussion and contending of these problems, strive for getting common understandings, and therefore promote the progress of researches of sedimentary facies and the development of sedimentology and palaeogeography.

What is "facies"? What is "sedimentary facies"? What is "lithofacies"? What is "microfacies"? What is "macrofacies"? What is "subfacies"?

It should start from clarifying what is "facies", i.e., the definition of "facies" firstly.

\section{Definitions of facies}

\subsection{Previous definition of facies}

In sedimentary petrology and sedimentology, not in igneous petrology, metamorphic petrology, stratigraphy, and other geological disciplines, the definition of facies has long been debated.

However, one point is basically agreed among the majority of sedimentologists, i.e., in sedimentary petrology and sedimentology, facies has to include features of sediments or sedimentary rocks and sedimentary environments.

Рухин (1953), a sedimentologist of USSR, in his textbook “основы литологии" (Principles of Sedimentary Petrology) considered: "Facies is the regular synthesis of sediments which can express their lithological and palaeontological features. Therefore, facies is the material expression of formation conditions of sediments. It should be to say lagoon dolostone facies but not to say dolostone facies. It should be to say lake (or lacustrine) siltstone facies but not to say siltstone facies."

Mineralogy and Petrology Section of Beijing Petroleum Institute (1961) synthesized the meaning of facies of 13 sedimentologists, mainly the sedimentologist of USSR, mainly Рухин (1953), and considered "Facies is the sum of features of sediments and their formation conditions".

Mineralogy and Petrology Section of East China Petroleum Institute (1982) considered "Facies is the synthesis of sedimentary environments and features of sedimentary rocks (sediments) formed in those sedimentary environments". This definition of facies succeeded that of Mineralogy and Petrology Section of Beijing Petroleum Institute (1961).

Feng (1994) in the "Sedimentary Petrology (Second Edition) also reiterated the definition of the Mineralogy and Petrology Section of East China Petroleum Institute (1982).

The "Glossary of Geology" by American Geological Institute (1973) mentioned many definitions of facies. One among these definitions is: "Facies is the sum of all 
primary lithologic and palaeontologic characteristics exhibited by a sedimentary rock and from which its origin and environment of formation may be inferred" .

The "Encyclopedia of Sedimentology" by Füirbridge and Bourgeois (1978) firstly cited the definition of facies proposed by Gressly (1838): "I call facies or aspects of stratigraphic unit: one is that a similar petrographic aspect ... ... ; the other, that a similar paleontological assemblage ......."

This sentence by Gressly (1838) may be the earliest statement of the definition of facies. It consists of petrographic aspect and paleontological assemblage and should be fully affirmed. As for "stratigraphic units" and sedimentary environments not mentioned in his definition, we should not be over-critical. Before 180 years, this statement of facies is very difficult of attainment and worthy of esteem.

The "Encyclopedia of Sedimentology" also cited the definition of facies by Moore (1949): "any areally restricted part of a designated stratigraphic unit which exhibits characters significantly different from those of other parts of the unit." It is worthy to be discussed and contended that in 1949 Moore duplicated the viewpoint of Gressly (1838). I don't agree with this viewpoint.

The "Encyclopedia of Sedimentology" cited another definition of facies: "Facies refers to the overall characteristics of rocks formed in a particular environment". I agree with this definition.

"A Dictionary of Earth Sciences" by the Editorial Committee of A Dictionary of Earth Sciences (2006), in its Basic Disciplines Volume, considered: "Sedimentary facies is the material expression of sedimentary environment. Sedimentary facies is the sum of all primary features, including petrological, palaeontological and petrogeochemical features, of sedimentary environment" . I agree with this definition.

\subsection{My definition of facies today}

Feng (2017) in his paper "Words of the Editor-in-Chief - Rocks are not microfacies" proposed: (1) Sedimentary rocks are not facies, (2) Sedimentary environments are not facies, (3) Sedimentary rocks plus sedimentary environments are facies, and the term "facies" is a simplified name of "sedimentary facies".

Now, I revise the above 3 sentences and add 2 sentences. It consists of 5 sentences.

The interpretations of these 5 sentences are as follows.

1) In the first sentence "Sedimentary rocks are not facies", the sedimentary rocks include all sedimentary rocks and their features. But, only sedimentary rocks and their features are not sedimentary facies.

2) In the second sentence "Sedimentary environments are not facies", the sedimentary environments include marine environments, continental environments, marine-continental transition environments, and their various subenvironments. But, only sedimentary environments are not facies.

3) The third sentence "The synthesis of sedimentary rocks and sedimentary environments is facies". It is the core of definition of facies. Here, I emphasize the "synthesis". It means that sedimentary rocks and sedimentary environments are inseparable in sedimentary facies. If they are separated, both sedimentary rocks and sedimentary environments are not facies any longer.

In sedimentary petrology or sedimentology, not in other geological disciplines, the term "facies" is a simplified name of "sedimentary facies". The "facies" and "sedimentary facies" are synonymic terms.

4) The fourth sentence "Sedimentary rocks formed in the sedimentary environments" is to explain the relationship between the sedimentary rocks and sedimentary environments.

5) Just because the "Sedimentary rocks formed in the sedimentary environments", therefore the fifth sentence "The features of sedimentary rocks can reflect their sedimentary environments in which the sedimentary rocks formed" . This sentence is very important. Except the modern sedimentary environments, all sedimentary environments in geological history disappeared long ago and we cannot see them with our eyes. But, they are knowable. By means of the data of various features of sedimentary rocks, including the macrofeatures and microfeatures of sedimentary rocks from outcrops, wells and laboratories, we can analyze, infer and reconstruct the sedimentary environments in geological history. It is facies analysis of sedimentary rocks. It is an important task of sedimentary petrology, sedimentology and palaeogeography.

In summary, the first and second sentences are negative words which negate the current incorrect viewpoints about sedimentary facies. The third sentence is the core of definition of sedimentary facies. The fourth sentence is to explain the relationship between sedimentary rocks and sedimentary environments. The fifth sentence is to explain that sedimentary environments in geological history which disappeared from our sight are knowable and therefore to point out the task of facies analysis of sedimentary rocks.

In a word, the above 5 sentences are my definition of sedimentary facies today. This definition is the succession and development of the 4 books by Рухин (1953), Mineralogy and Petrology Section of Beijing Petroleum Institute (1961), Mineralogy and Petrology Section of East China Petroleum Institute (1982), and Feng (1994). 
According to the definitions of sedimentary facies of the above 4 text books and mine, it should be to say pluvial conglomerate facies but not to say conglomerate facies, it should be to say river (or fluvial) sandstone facies but not to say sandstone facies, it should be to say lake (or lacustrine) mudstone facies but not to say mudstone facies, it should be to say carbonate bank oolitic limestone facies but not to say oolitic limestone facies, etc.

\section{Classification and terminology of facies}

In sedimentary petrology and sedimentology, the classification and terminology of facies are also all along in debate, and the problems may be more than that of the definition of facies.

This paper mainly states the principal sedimentary facies and discusses their relevant problems. Please see Table 1.

Table 1 is the succession and development of 3 books of "Sedimentary Petrology" by Mineralogy and Petrology Section of Beijing Petroleum Institute (1961), Mineralogy and Petrology Section of East China Petroleum Institute (1982), and Feng (1994) respectively.

Some discussions about the problems of the classification and terminology of sedimentary facies in Table 1 are as follows.

1) The "1st-order facies" and "2nd-order facies" in Table 1 are added by the author at this time. It is necessary to indicate the order of various names of sedimentary facies in the classification and terminology.

2) Most facies names in Table 1 are not normalized, because they only include sedimentary environments while lacking sedimentary rocks or their features. If the word "sediments" is added to these facies names in Table 1 and they can be written out as continental sediments facies, marine sediments facies, river sediments facies, shallow sea sediments facies, delta sediments facies, etc., then they are consistent with the definition of facies. But, these current facies names are conventional and widely used which are difficult to be revised. We have to think that in order to simplify the facies names, the word "sediments" should be omitted.
3) In the marine facies of the above 3 books "Sedimentary Petrology", there existed "semi-deep sea facies". Due to the lack of reliable identification markers of this facies, I deleted it.

4) In the marine-continental transition facies of the above 3 books, there existed lagoon facies, barrier facies and tidal facies. Now, I consider that the 3 facies should belong to littoral facies, i.e., the suborder facies of littoral facies, and therefore I assign them under the littoral facies of marine facies. As for the estuary facies, it may belong to marine-continental transition facies or marine facies, and therefore I did not change its position. In the marine-continental transition facies, only delta facies is universally accepted by sedimentologists.

5) Some sedimentologists named the "mountain foot pluvial facies" as "alluvial facies" or "alluvial fan". They can call it as that. However, it should be clarified that this "alluvial fan" is different from the "mountain foot pluvial fan". About "mountain foot pluvial facies", I emphasize the "mountain foot" which is a key point to differentiate the "pluvial facies" from "river (fluvial) facies".

6) In fact, in order to simplify the facies names, if the authors omit the term "facies", while remain "sedimentary environments", add the word "sediments", and then name them as continental sediments, marine sediments, marine-continental sediments, river sediments, lake sediments, shallow sea sediments, deep sea sediments, delta sediments, etc., these facies names may be more simplified and consistent with the definition of sedimentary facies.

In a word, there are many problems worthy to be discussed in the classification and usage of terminology of these principal 1st-order facies and 2nd-order facies.

As for the classification and usage of terminology of 3rd-order facies, 4th-order facies and subsequent suborder facies, the problems may be more and may be different from different sedimentologists. However, one point should be observed, i.e., the names of various order facies should consist of sedimentary environments and sedimentary rocks or the features of sedimentary rocks.

Table 1 Principal sedimentary facies

\begin{tabular}{llll}
\hline 1st-order facies & Continental facies & Marine facies & Marine-continental transition facies \\
\hline 2nd-order facies & 1. Residual facies & 1. Littoral facies & 1. Delta facies \\
& 2. Debris and slope facies & 2. Shallow sea facies & 2. Estuary facies \\
& 3. Mountain foot pluvial facies & 3. Deep sea facies & \\
4. River (fluvial) facies & \\
5. Lake (Lacustrine) facies & \\
6. Swamp facies & \\
7. Desert facies & & \\
8. Glacial facies & \\
\hline
\end{tabular}




\section{The "subfacies" and "microfacies" proposed by Chinese sedimentologists}

4.1 The "subfacies" and "microfacies" proposed by Mineralogy and Petrology Section of East China

Petroleum Institute (1982)

The Mineralogy and Petrology Section of East China Petroleum Institute (1982) divided river facies (2ndorder facies) into 4 subfacies, i.e., river channel subfacies, shore levee subfacies, flood plain subfacies and oxbow lake subfacies.

The Mineralogy and Petrology Section of East China Petroleum Institute (1982) further divided river channel subfacies into 3 microfacies, i.e., channel residual microfacies, point bar microfacies, and channel bar microfacies; further divided shore levee subfacies into 2 microfacies, i.e., natural levee microfacies and splay microfacies; and further divided flood plain subfacies into 3 microfacies, i.e., flood beach microfacies, flood lake microfacies and flood swamp microfacies.

The Mineralogy and Petrology Section of East China Petroleum Institute (1982) also divided other 2nd-order facies into some subfacies and some microfacies.

These subfacies are 3rd-order facies. These microfacies are 4th-order facies.

4.2 The "subfacies" and "microfacies" proposed by Zhang (1980, 1985)

Zhang $(1980,1985)$ studied the coarse-grained clastic alluvial fan of the Middle Triassic in Karamay, Xinjiang, northwestern China, and divided alluvial fan into 3 subfacies, i.e., top fan, mid fan, and fringe fan. He further divided top fan into different microfacies, i.e., main channel, fringe channel, channel beach, flood zone, flow gully, gully beach, etc. He further divided mid fan into different microfacies, i.e., flood-flow zone, braided-flow sand island, braided-flow line, etc.
The coarse-grained clastic alluvial fan of the Middle Triassic in Karamay studied by Zhang $(1980,1985)$ is a mountain foot pluvial fan, i.e., the 2nd-order facies, and therefore his subfacies are 3rd-order facies and his microfacies are 4th-order facies.

Zhang may be the first Chinese sedimentologist to divide the alluvial fan into subfacies and microfacies by means of petrological features of field outcrop. It is helpful for fine researches in sedimentology.

\subsection{The "subfacies" and "microfacies" proposed by Zhao and Liu (1984)}

Zhao and Liu (1984) studied the member 4 and member 3 of Paleogene Shahejie Formation in Bohai Bay area and divided the sublacustrine fan into 5 subfacies and 8 microfacies. Please see Table 2.

The "sublacustrine fan" is a suborder facies of lake facies (2nd-order facies), i.e., a 3rd-order facies, and therefore the "subfacies" proposed by Zhao and Liu (1984) in Table 2 are 4th-order facies and their "microfacies" are 5thorder facies. The orders of the subfacies and microfacies proposed by Zhao and Liu (1984) are lower than those by Mineralogy and Petrology Section of East China Petroleum Institute (1982) and Zhang 1980, 1985.

It is a progress in the researches of sedimentary facies that Zhao and Liu (1984) divided the sublacustrine fan into subfacies and microfacies by means of study of the cores.

In a word, the Chinese sedimentologists in 1980s defined the subfacies and microfacies of different study areas in China through their meticulous work to study the outcrops and cores. It indicates that researches of continental facies by Chinese sedimentologists have reached a rather high level. It is a contribution to the exploration and development of oil and gas.

After 1980s, a lot of Chinese sedimentologists started to utilize the terms "subfacies" and "microfacies".

Table 2 Subfacies and microfacies of the sublacustrine fan of the member 4 and member 3 of Paleogene Shahejie Formation in Bohai Bay area (from Zhao and Liu, 1984)

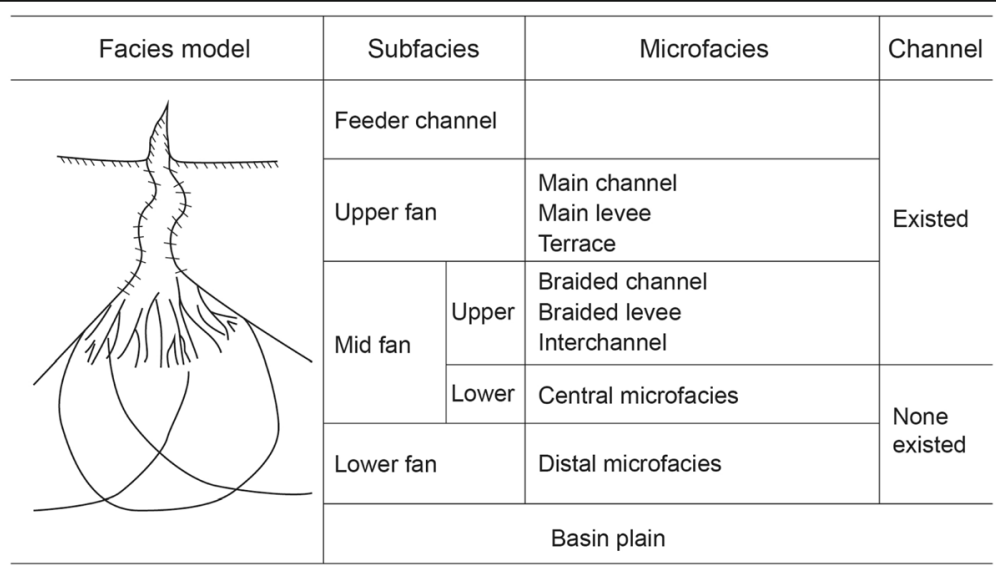


Now, I cite 25 papers from the Journal of Palaeogeography (Chinese Edition) 2014-2018 as examples to illustrate the general status.

\subsection{The "subfacies" and "microfacies" used in the Journal} of Palaeogeography (Chinese Edition) during 2014-2018 In the Journal of Palaeogeography (Chinese Edition), 25 papers stated"facies", "subfacies" and "microfacies"systematically.

From these papers, we can understand 3 points: (1) These papers stated the relationship of facies orders i. e., "subfacies is a suborder facies of "facies", "microfacies" is a suborder of "subfacies" and "microfacies" is a minimum order facies. It means that "microfacies" are difficult to be divided into suborder facies any more. (2) The "microfacies" are not only in clastic rocks of continental facies and marine-continental/transition facies, but also in carbonate rocks of marine facies. (3) Most "microfacies" are defined on the basis of macrofeatures of clastic rocks of outcrops and cores.

These papers can reflect the general study situation of "subfacies" and "microfacies", especially the "microfacies" in Chinese journals during the recent years after 1980s.

\subsection{My ideas}

1) The term "subfacies" can be called "suborder facies". It is a term of general sense. Most facies may have their suborder facies, i.e., subfacies, and therefore the term "subfacies" is not limited to some definite order facies, such as 3rd-order facies of Zhang $(1980,1985)$ and 4th-order facies of Zhao and Liu (1984).

2) Similarly, the term "microfacies" is not limited to some definite order facies either, such as 4th-order facies of Zhang $(1980,1985)$ and 5th-order facies of Zhao and Liu (1984). Please see the above Table 1 and Table 2.

3) Therefore, in the study of sedimentary facies and in utilization of the terms "subfacies" and "microfacies", the names of their higher order facies should be clearly indicated.

4) In fact, in the study of sedimentary facies, when sedimentologists already defined the names of "subfacies" and "microfacies" and already indicated their facies orders and their higher order facies names, if the authors omitted the terms "subfacies" and "microfacies", while remained the core facies names (please see Table 2), added the word "sediments" behind the core facies name and finally named them as "upper fan sediments", "mid fan sediments", "main channel sediments", "braided channel sediments", etc., the names of "subfacies" and "microfacies" are more simplified and consistent with the definition of sedimentary facies.
5) However, the term "microfacies" proposed by Chinese sedimentologists is problematic, because most "microfacies" are not "micro". They are not defined on the basis of microfeatures of thin-sections under microscope but according to macrofeatures of outcrops and cores.

6) In addition, "microfacies" proposed by Chinese sedimentologists was later than that proposed by foreign sedimentologists. Please see the following.

\section{The "microfacies" proposed by foreign sedimentologists}

5.1 The "microfacies" used in early time

Brown (1943) may be the earliest sedimentologist who put forward the term "microfacies". His definition of this term is "Microfacies refers to the criteria appearing in thin-sections under the microscope".

Cuvillier (1952) also mentioned "microfacies". His definition is "Microfacies (refers) to characterize paleontological and petrographic criteria in thin-sections".

\subsection{The "standard microfacies" proposed by Wilson (1975a, b)}

Wilson (1975a, b) in his book "Carbonate Facies in Geologic History" put forward "24 standard microfacies" and indicated their positions in the " 9 standard facies belts".

However, Wilson (1975a, b) did not give a definition of "microfacies".

According to the names and explanations of their photos under microscope, we can understand that except the "standard microfacies 3", i.e., the "pelagic lime mudstone" which consists of sedimentary environment and sedimentary rock, the other 23 "standard microfacies" are all the names of rocks or rock types which lacked sedimentary environment information. They are mainly the petrological and paleontological features of rocks or rock types under microscope. Therefore, the 23 "standard microfacies" are not facies but the microfeatures of 23 rocks or rock types.

Certainly, it is right that Wilson (1975a, b) put forward the "9 standard facies belts". It is a great contribution to the researches of carbonate facies.

When I and my collaborators translated the book "Carbonate Facies in Geologic History" into Chinese version, I found that 23 "microfacies" are not facies but the microfeatures of rock types. It is a problem of this famous work of Wilson (1975a, b). However, I did not point out the problem in my "Preface of translator" of its Chinese version. At that time, my understanding was not clear and I thought it is a problem of different academic viewpoints. But, in recent years, when I found some domestic authors cited the "standard microfacies" of Wilson (1975a, b) and considered the rocks or rock types as "microfacies", I began to realize that it is not 
only a problem of different academic viewpoints but also a scientific problem of "right or wrong". Therefore, I felt guilty, i.e., I did not discharge the responsibility as a chief translator.

Now, I want to express my regret to Chinese readers that among the "24 standard microfacies" of Wilson (1975a, b), 23 "standard microfacies" are not "facies" but the microfeatures of rock types. Certainly, the "9 standard facies belts" in which the "24 standard microfacies" were located are right.

5.3 The "microfacies" proposed by Flügel (1982, 2004a, b, 2010a, b)

In the book "Microfacies Analysis of Limestones" by Flügel (1982), the definition of microfacies is "microfacies is the total of all the paleontological and sedimentological criteria which can be classified in thin-sections, peels and polished slabs".

In the book "Microfacies of Carbonate Rocks: Analysis, Interpretation and Application" by Flügel (2004a, b), the definition of microfacies is "As original defined by Brown (1943) and again independently by Cuvillier (1952) the term "microfacies" referred only to petrographic and paleontological criteria in thin-sections. Today, however, microfacies is regarded as the total of all sedimentological and paleontological data which can be described and classified from thin sections, peels, polished slabs or rock samples."

In the book of "Microfacies of Carbonate Rocks: Analysis, Interpretation and Application, Second Edition" by Flügel $(2010 a, b)$, the definition of microfacies is the same as Flügel (2004a, b).

However, about the definition of "microfacies" in the two Chinese versions of Flügel 2004a, b, 2010a, b), the translators $\mathrm{Ma}$ et al. added a sentence, i.e., "The term of microfacies has been a comprehensive term".

In January 2018, the authors of a manuscript submitted to the Journal of Palaeogeography (English Edition) cited this sentence as original words of the definition of microfacies by Flügel (2004a, b, 2010a, b).

\subsection{My ideas}

1) "The petrological and paleontological criteria in thinsections under microscope" are the principal and decisive contents of the definition of "microfacies", while "the criteria in peels, polished slabs and rock samples" are the secondary contents of the definition of "microfacies", and the other words, such as "which can be classified" , etc., are unnecessary. "The term of microfacies has been a comprehensive term" proposed by $\mathrm{Ma}$ et al. may be suitable to be put in the translator preface of Chinese version of Flügel (2004a, b, 2010a, b).
2) According to the principal and decisive content of the definition of "microfacies", we can consider that the term "microfacies" was problematic from its beginning. The main problem is "its name does not match the reality".

The "microfacies" are not "facies" because they do not contain the content of sedimentary environments. The "microfacies" are not rocks but the microfeatures of rocks instead. Strictly speaking, the "microfacies" are the microfeatures of carbonate rocks.

3) Therefore, the term "microfacies" is not suitable to be utilized any more.

4) However, a lot of sedimentologists and relevant experts of petroleum exploration and development still utilize the term "microfacies" today. This phenomenon resulted from the milestone's innovation of carbonate petrology starting from 1950s-1960s, i.e., it resulted from the history of rapid development of carbonate petrology. Now, I think that the term "microfacies" is not suitable to be utilized any more, which may be the unpleasant words for relevant sedimentologists and experts.

But, I don't negate the great contribution of Wilson (Wilson 1975a, b) and Flügel (1982, 2004a, b, 2010a, b) to carbonate petrology. It is also a great contribution that Ma. et al. translated the famous works of Flügel (2004a, b, 2010a, b) into Chinese. Here, I only point out the problem that the name of "microfacies" does not match the reality and therefore the term "microfacies" is not suitable to be utilized any more.

5) In a word, the term "microfacies" proposed by foreign sedimentologists appeared in the history of rapid development of carbonate petrology, whether it is unsuitable to be utilized continuously or not, will be decided by free discussion and contending among the geologists worldwide and by the future geological practice.

\section{Two "microfacies" with different definitions}

As mentioned above, there are two "microfacies" with different definitions in sedimentary petrology and sedimentology. One is the "microfacies" in continental clastic facies proposed by Chinese sedimentologists in 1980s, the other is the "microfacies" in marine carbonate facies proposed by foreign sedimentologists in 1940s.

The term "microfacies" proposed by Chinese sedimentologists contains both sedimentary environments and sedimentary rocks or their features and is consistent with the definition of sedimentary facies. While the term "microfacies" proposed by foreign sedimentologists only 
contains the features of sedimentary rocks, mainly the features of carbonate rocks but without the sedimentary environment information, and therefore is not consistent with the definition of sedimentary facies.

Nowadays, there are two "microfacies" with different definitions in sedimentary petrology and sedimentology at the same time. It is a problem indeed.

My ideas are as follows:

1) The term "microfacies" is a facies, thus it must be consistent with the definition of sedimentary facies. This principle is fundamental. The term "microfacies" proposed by Chinese sedimentologists is consistent with the definition of sedimentary facies and it can be utilized continuously. While the term "microfacies" proposed by foreign sedimentologists is not consistent with the definition of sedimentary facies, and it is unsuitable to be utilized any more.

2) However, whether the "microfacies" proposed by foreign sedimentologists is suitable to be utilized continuously or not, should be settled through discussion and contending among geologists and sedimentologists worldwide and let the future geological practice solve this problem gradually. This problem can not be solved immediately.

3) The term "microfacies" proposed by Chinese sedimentologists is also problematic, mainly its name is unsuitable. Most "microfacies" proposed by Chinese sedimentologists, especially in 1980s, were defined according to macrofeatures of outcrops and drilling cores. Most of them are not "micro". In addition, the term "microfacies" proposed by foreign sedimentologists in 1940s was earlier than that by Chinese sedimentologists in 1980s. Therefore Chinese sedimentologists have to understand that foreign sedimentologists have the precedence or priority over Chinese sedimentologists in terminology of the term "microfacies". It means that Chinese sedimentologists have no right to change the definition of "microfacies" proposed by foreign sedimentologists, although the term "microfacies" proposed by Chinese sedimentologists is consistent with the definition of sedimentary facies.

4) So, I suggest that Chinese sedimentologists do not utilize the term "microfacies" continuously and state their viewpoints according to the above mentioned contents in "3.4": In the study of sedimentary facies, when the authors had already defined the name of "microfacies" and indicated its facies order and the name of its higher order facies, if the authors omitted the term "microfacies", while remained the core name of the "microfacies" (please see Table 2), added the word "sediments" behind the core name, and then finally named them as "main channel sediments", "main levee sediments", "braided channel sediments", "braided levee sediments" etc.

It is totally feasible and consistent with the definition of sedimentary facies. It does not influence the study degree of sedimentary facies.

I hope Chinese sedimentologists can agree with my suggestion, i.e., they do not utilize the term "microfacies" continuously, and should not be involved in the troubles of "microfacies" of foreign sedimentologists.

\section{7 "Macrofacies"}

The term "macrofacies" is rarely used by geologists.

The "Glossary of Geology" by American Geological Institute (1973) only used two words "facies tract" to interpret this term "macrofacies".

In "the Encyclopedia of sedimentology" by Füirbridge and Bourgeois (1978), there was no such a term.

The "English-Chinese Dictionary of Geology" by Editorial Group of English-Chinese Dictionary of Geology (1983) translated the term "macrofacies" into "great lithofacies” (大岩相) and “facies tract” (相域).

I do not approve of the term "facies tract" and disagree with the term "great lithofacies" either.

In fact, "macrofacies" refers to the macrofeatures of sedimentary rocks. It is an opposite term to "microfacies". It is not consistent with the definition of facies and therefore should not be utilized any more.

\section{8 "Lithofacies"}

The term "lithofacies" is a widely used term in Chinese sedimentary petrology, sedimentology and palaeogeography, however, its definition is debated.

The "Glossary of Geology" by American Geological Institute (1973) mentioned 4 definitions of the term "lithofacies" among which one viewpoint is: "A term used by Moore (1949) to signify any particular kind of sedimentary rock or distinguishable rock record formed under common environmental conditions, ... ... , and represented by the sum total of the lithologic characteristics (including both physical and biologic characters) of rock"

In fact, in the conclusion of Moore's paper (Moore 1949), he concluded a more concise definition of the term "lithofacies": "The rock record of any sedimentary environment, including both physical and organic characters, is designated by the term "lithofacies"”.

I agree with the definition of "lithofacies" by American Geological Institute (1973) and Moore (1949).

"A Dictionary of Earth Sciences, Basic Disciplines Volume" by the Editorial Committee of A Dictionary of Earth Sciences (2006) considered: Lithofacies refers to the facies of sedimentary rocks. It reflects the features of a certain sedimentary environment, including all the 
physical, chemical (mineralogical and petrological) and biological features, such as a glauconitic sandstone facies of marine strata in Paleozoic which reflected shallow sea environment.

I agree with this definition of "lithofacies".

My idea is: in sedimentary petrology and sedimentology, not in other geological disciplines, lithofacies is the facies of sedimentary rocks. "Lithofacies", "facies" and "sedimentary facies" are synonymic terms. It is a correct choice.

Therefore, the term "lithofacies" should be utilized continuously.

But, only the sedimentary rocks or the features of sedimentary rocks without sedimentary environments are not "lithofacies", i.e., the sedimentary rocks or rock types are not "lithofacies".

I have been engaged in teaching and researches of sedimentology and lithofacies palaeogeography for more than 60 years and I all along considered "lithofacies" as "sedimentary facies".

Till today, I don't know who is the first person to consider sedimentary rocks or rock types as "lithofacies".

\section{A hundred flowers blossom and a hundred schools of thought contend}

Mao (1937) said: "Many theories of natural science are held to be true not only because they were so considered when natural scientists originated them, but also because they have been verified in subsequent scientific practice. ... ... The history of human knowledge tells us that the truth of many theories is incomplete and that the incompleteness is remedied through the test of practice. Many theories are erroneous and it is through the test of practice that their errors are corrected".

Mao (1957) also said: "A hundred flowers blossom and a hundred schools of thought contend is the policy for promoting progress in the arts and sciences. ... ... Questions of right and wrong in the arts and sciences should be settled through free discussion in artistic and scientific circles and through practical work in these fields. They should not be settled in an over-simple manner".

I observe the policy of " $A$ hundred flowers blossom and a hundred schools of thought contend" and write the papers "A review on the definitions of terms of sedimentary facies" both in Chinese and English. I hope this paper can attract attention of readers worldwide and they can write papers and participate in the discussion and contending of these problems and promote the progress of sedimentology and palaeogeography.

In order to carry out the policy of "A hundred flowers blossom and a hundred schools of thought contend", we should observe the following rules: (1) We should uphold truth and correct mistakes. The viewpoints should be definite and clear. (2) The speaking should be on grounds. (3) The speaking should not be with harsh words and will not injure the personal dignity with opposite viewpoints. (4) We should be with patience, because some academic problems may not be solved by one or two academic discussions, and may be finally solved by the future geological practice.

I am willing to observe the above rules together with the readers and authors who are willing to participate in this academic discussion and contending.

\section{Conclusions}

From the mentioned above, the following conclusions are acquired.

1) About the definition of facies

In sedimentary petrology and sedimentology, what is facies? It is all along in debate.

My definition of facies is: (1) Sedimentary rocks are not facies. (2) Sedimentary environments are not facies. (3) The synthesis of sedimentary rocks and sedimentary environments is facies, and the term "facies" is a simplified name of "sedimentary facies". (4) Sedimentary rocks formed in sedimentary environments. (5) The features of sedimentary rocks can reflect their sedimentary environments in which the sedimentary rocks formed.

2) About the classification of sedimentary facies

In sedimentary petrology and sedimentology, sedimentary rocks and sedimentary environments are various, and sedimentary facies are more various. The marine facies, continental facies, and marine-continental transition facies are the 1st-order facies. They can be divided into suborder facies, such as 2nd-order facies, 3rd-order facies, 4th-order facies, 5th-order facies, etc. The names of different order facies are even more various and may be different among different sedimentologists. But one point should be observed, i.e., the various order facies should contain sedimentary environments and sedimentary rocks or the features of sedimentary rocks.

3) About "lithofacies"

"Lithofacies" is the facies of sedimentary rocks. It is a simplified name of "sedimentary facies". "Lithofacies", "facies" and "sedimentary facies" are synonymic terms. "Lithofacies" can be utilized continuously.

But, sedimentary rocks or rock types are not "lithofacies".

4) About "microfacies" 
Today, in sedimentary petrology and sedimentology, there are two "microfacies" with different definitions. It is a serious problem.

One is the "microfacies" proposed by foreign sedimentologists in 1940s, the other is the "microfacies" proposed by Chinese sedimentologists in 1980s.

The "microfacies" proposed by foreign sedimentologists only contains the microfeatures of sedimentary rocks, mainly the microfeatures of carbonate rocks in thin-sections under microscope but without the sedimentary environments. It is not consistent with the definition of sedimentary facies and therefore it is unsuitable to be utilized any more. However, whether the "microfacies" of foreign sedimentologists is unsuitable to be utilized or not, should be testified through discussion and contending of numerous geologists and sedimentologists worldwide and let the future geological practice solve the problem. This problem can not be solved at once.

The "microfacies" proposed by Chinese sedimentologists contains both the features of sedimentary rocks and sedimentary environments. It is consistent with the definition of sedimentary facies and thus it can be utilized continuously. But, the "microfacies" proposed by Chinese sedimentologists is also problematic, because most "microfacies" defined by Chinese sedimentologists are according to macrofeatures of outcrops and drilling cores and are not "micro". In addition, they are proposed later than those defined by foreign sedimentologists, and therefore the foreign sedimentologists have the precedence or priority over Chinese sedimentologists. So, I suggest that Chinese sedimentologists do not utilize the term "microfacies" continuously and do not be involved in the troubles of "microfacies" of foreign sedimentologists.

\section{5) About "macrofacies"}

The "macrofacies" proposed by some sedimentologists are not "facies" but are macrofeatures of rocks. Therefore, the term "macrofacies" is not consistent with the definition of sedimentary facies, and is unsuitable to be utilized continuously.

\section{6) About "subfacies"}

The term "subfacies" can be called "suborder facies". It is a term of general sense. Most facies may have their suborder facies, i.e., subfacies, and therefore the term "subfacies" is not limited to some definite order facies. In fact, in the study of sedimentary facies, if the authors do not utilize the term "subfacies" but utilize its core facies name instead, it may be more simplified. However, the authors should indicate its facies order and its higher order facies name.

\section{7) A hundred flowers blossom and a hundred schools of thought contend}

In sedimentary petrology and sedimentology, the definitions of "facies", "sedimentary facies", "lithofacies", "microfacies", "macrofacies" "subfacies", etc., are all along in debate. These debates are not only the problems of different academic viewpoints but some problems are regarding right or wrong. Therefore, it is necessary to clarify the definitions of these terms definitely and clearly.

We should observe and carry out the policy of " $A$ hundred flowers blossom and a hundred schools of thought contend", and should settle these problems through free discussion and contending. We should not blindly worship celebrity. The words of a famous person are not $100 \%$ correct. We should seek the truth from facts. We should not only uphold the truth, but also correct mistakes. Let free discussion and contending and the future geological practice solve these problems gradually and successfully.

\section{Acknowledgements}

I heartily thank Xiu-Juan Zheng, Xin-Po Li, Xi-Juan Zhang, Yuan Wang and Min Liu for their helpful comments and corrections of the original Chinese and English manuscripts of this paper. I heartily thank Yuan Wang who carefully corrected and polished the English manuscript. I heartily thank Xiao-Ming Wu and Yun-Jia Yang for their repeated typewriting work for more than 20 times. Without their support, it is difficult for me to complete the Chinese and English manuscripts.

I heartily thank Prof. Chun-Ming Lin, Prof. Da-Kang Zhong and Prof. Long-Yi Shao for their academic comments and suggestions.

I specially thank Profs. Ian D. Somerville, G. Shanmugam, Santanu Banerjee and Ya-sheng Wu who reviewed the English manuscript, and Profs. JingShan Chen, Yuan-Sheng Du, Xing-He Yu and Ya-Sheng Wu who reviewed the Chinese manuscript. Their comments promoted the supplement,

corrections and refinement of the papers and therefore improved the academic level of the papers. Their comments made the papers receive a rigorous test by "A hundred flowers blossom and a hundred schools of thought contend" before the publication. I extremely thank the above reviewers!

Author's contributions

FZZ wrote and revised the original version of the manuscript. FZZ approved the final version of the manuscript.

Competing interests

The author declares that he has no competing interests.

Received: 12 September 2018 Accepted: 6 September 2019

Published online: 15 November 2019

\section{References}

American Geological Institute. 1973. Glossary of geology, 1-805. Washington, D. C: American Geological Institute.

Brown, J.S. 1943. Suggested use of the word microfacies. Economic Geology 38: 325.

Cuvillier, J. 1952. Le notion de "microfacies" et ses applications, VII Congreso Nazionale di Metano e Petroleo, sect. 1, 1-7.

Editorial Committee of A Dictionary of Earth Sciences. 2006. A Dictionary of Earth Sciences, Basic Disciplines Volume, 1-1173. Beijing: Geological Publishing House in Chinese. 
Editorial Group of English-Chinese Dictionary of Geology. 1983. EnglishChinese Dictionary of Geology, 1-1142. Beijing: Geological Publishing House (in English and Chinese).

Feng, Z.Z. 1994. Sedimentary petrology. Vol. 1, 1-368. Beijing: Petroleum industry press Vol.2, 1-326(in Chinese).

Feng, Z.Z. 2017. Words of the editor-in-chief - Rocks are not microfacies. Journal of Palaeogeography (Chinese Edition) 19 (5): II (in Chinese).

Feng, Z.Z. 2018. Words of the editor-in-chief - Rocks are not lithofacies. Journal of Palaeogeography (Chinese Edition) 20 (3): 452-452 (in Chinese).

Flügel, E. 1982. Microfacies analysis of limestone. Translated by K. Christenson, 1-633. Berlin, Heidelberg New, York: Springer-Verlag.

Flügel, E. 2004a. Microfacies of carbonate rocks: Analysis, Interpretation and Application, 1-976. Berlin, Heidelberg, New York: Springer.

Flügel, E., 2004b. Translated by Ma Yong-Sheng et al., 2006. Microfacies of carbonate rocks: Analysis, interpretation and application (Chinese version). Geological Publishing House, Beijing, 1-882.

Flügel, E. 2010a. Microfacies of carbonate rocks: Analysis, interpretation and application. 2nd ed, 1-984. Dordrecht London New York: SpringerHeidelberg.

Flügel, E., 2010b. Translated by Ma Yong-Sheng, Liu Bo, Guo Rong-Tao et al., 2016. Microfacies of carbonate rocks: Analysis, interpretation and application, second edition (Chinese version). Geological Publishing House, Beijing, 1-832.

Füirbridge, R.W., and J. Bourgeois. 1978. The encyclopedia of sedimentology, 1-901. Hutchingson \& Ross Inc.: Dowden.

Gressly, A. 1838. Observations géologiques sur le Jura Soleurois. Nouv. Mém. Soc. Helv. Sci. Natur 2: 349.

He, Y.B., and W.G. Wang. 2007. Sedimentary rocks and sedimentary facies, 1290. Beijing: Petroleum Industry Press (in Chinese).

Hou, E.G., J.H. Gao, X.L. Wang, G.H. Wang, X.R. Hu, Z. Ma, and C. 2014 Carbonate petrological characteristics and sedimentary environment of the upper Triassic Riganpeicuo formation at Renacuo area, Gaize, Tibet. Journal of Palaeogeography (Chinese Edition) 16 (3): 347-358 (in Chinese with English abstract).

Liu, D.W., Y.L. Ji, C.L. Gao, J. Jin, Z. Ynag, X.B. Duan, Z.J. Huan, and N.N. Luo. 2018. Microfacies and sedimentary models of gravelly braided-river alluvial fan: A case study of modern Baiyanghe-river alluvial fan in northwestern margin of Junggar Basin. Journal of Palaeogeography (Chinese Edition) 20 (3): 435-451 (in Chinese with English abstract).

Mao, T.T. 1937. On practice. In Selected works of Mao Tse-Tung, vol. 1, 295309. Peking: Foreign language press.

Mao, T.T. 1957. On the correct handling of contradictions among the people. In Selected works of Mao Tse-Tung, vol. 5, 384-421. Peking: Foreign language press.

Mineralogy and Petrology Section of Beijing Petroleum Institute. 1961. Sedimentary Petrology, 1-263. Beijing: China Industry Press in Chinese.

Mineralogy and Petrology Section of East China Petroleum Institute. 1982. Sedimentary Petrology. Vol. 2, 1-256. Beijing: Petroleum, Industry Press in Chinese.

Moore, R.C. 1949. Meaning of facies. Vol. 39, 1-34. Memior: The Geological Society of American.

Wilson, J.L. 1975a. Carbonate facies in geologic history, 1-471. Berlin Heidlberg New York: Springer-Verlag.

Wilson, J. L., 1975b. Translated by Feng Zeng-Zhao et al., 1981. Carbonate facies in geologic history (Chinese version). Geological Publishing House, Beijing, 1-365.

Xi, S.L., Y. Xiong, X.Y. Liu, J.C. Lei, M.J. Liu, L. Liu, Y. Liu, H.B. Wen, and X.C. Tan. 2017. Sedimentary environment and sea level change of the subsalt interval of member 5 of Ordovician Majiagou formation in Ordos Basin. Journal of Palaeogeography (Chinese Edition) 19 (5): $773-$ 790 (in Chinese with English abstract).

Zhang, J.Y. 1980. Coarse clastic alluvial fan and reservoir in Xinjiang, China. Xinjiang Petroleum Geology 1: 33-53 (in Chinese).

Zhang, J.Y. 1985. Some depositional characteristics and microfacies subdivision of coarse clastic alluvial fans. Acta Sedimentologica Sinica 3 (3): 75-85 (in Chinese with English abstract).
Zhao, C. L., and M. H. Liu. 1984. Facies model of the sublake-fan and its application to oil and gas exploration. Journal of Petroleum Institute 4(4): 323-334 (in. Chinese with English abstract).

Рухин, Л.Б. 1953, Translated by Zhang Jietao et al. 1955. основы литологии (Principles of Sedimentary Petrology), 2. Geological Publishing House, Beijing, 1-174 (in Chinese).

\section{Publisher's Note}

Springer Nature remains neutral with regard to jurisdictional claims in published maps and institutional affiliations.

\section{Submit your manuscript to a SpringerOpen ${ }^{\circ}$ journal and benefit from:}

- Convenient online submission

- Rigorous peer review

- Open access: articles freely available online

- High visibility within the field

- Retaining the copyright to your article

Submit your next manuscript at $\boldsymbol{\nabla}$ springeropen.com 